\title{
URINARY INCONTINENCE IN ELDERLY FROM A VIEW OF A PHARMACIST: DETRUSOR IMPAIRMENT AND TREATMENT
}

Turkish Journal of Geriatrics

DOI: 10.31086/tjgeri.2018137972

2018;21 (1):100-107

- Nezahat Tuğba

DURLU KANDILC ${ }^{1}$

\section{Abstract}

Aging results in impairments in the bladder function and causes alterations in many organs. In recent clinical studies, aging has been shown to alter the bladder function based on the observed decrease in filling, storage and emptying capacities of the bladder. In experimental studies, it has been postulated that aging changes the bladder function via symptoms such as a decrease in its voiding efficacy and an unwanted increase in its activity. This causes enuresis, also known as urinary incontinence, an important social concern that negatively affects the quality of the patient's social life. The incidence of urinary incontinence is particularly an issue in older women; the adverse effects of the drugs used for treatment and compliance issues prevent a successful treatment. In some studies examining the effects of aging on rat bladder, it has been proposed that the intracellular signalling mechanisms of agonist-induced contractile responses may be altered with an increase in age. The permeabilised smooth muscle mode is an efficient tool for investigating the functions of contractile proteins and intracellular organelles, which play a role in smooth muscle contractions. This model facilitates the study of the contractile functions in young and old animals to develop new drug molecules for the treatment of urinary incontinence. Although currently, antimuscarinic drugs are primarily used for the treatment of this condition, their adverse effects limit their efficacy.

Keywords: Aged; Urinary incontinence; Quality of life.
CORRESPONDANCE

Nezahat Tuğba DURLU KANDiLCi

Hacettepe University, Faculty of Pharmacy

Department of Pharmacology

Ankara, Turkey

Phone: 3123051088

e-mail: ndurlu@hacettepe.edu.tr

Received: 06/12/2017

Accepted: 09/02/2018

Hacettepe University, Faculty of Pharmacy Department of Pharmacology Ankara, Turkey
DERLEME MAKALE

\section{ECZACI BAKIŞ AÇISIYLA YAŞLILARDA ÜRINER INKONTINANS: DETRUSOR HASARI VE TEDAVI}

\section{$\ddot{O}_{z}$}

Yaşlanma, mesane fonksiyonlarında bozukluklara yol açmaktadır ve birçok organda değişikliğe neden olmaktadır. Son zamanlarda yapılan klinik çalışmalarda, yaşlanmanın mesanenin fonksiyonlarını mesanenin dolum, depolama ve boşaltım fonksiyonlarında azalmaya bağlı olarak değiştirdiği gösterilmiştir. Deneysel çalışmalarda ise, yaşlanmanın mesane fonksiyonlarını işeme efektivitesinde azalma ve mesane aktivitesinde istenilmeyen artış gibi bazı semptomlar aracılığı ile değiş̧tirdiği gösterilmiştir. Bu da idrar tutamama yani üriner inkontinans gibi hastanın sosyal yaşam kalitesini negatif olarak etkileyen önemli bir sosyal probleme neden olmaktadır. Üriner inkontinans görülme sıklığı özellikle yaşlı kadınlarda önemli bir konudur; tedavide kullanılan ilaçların yan etkileri ve hastaların uyunç problem başarılı bir tedaviyi önlemektedir. Sıçan mesanesi üzerine yaşlanmanın etkisini inceleyen bazı çalışmalarda, agonist ile indüklenen kasılma yanıtlarının hücre içi sinyal iletim mekanizmalarının yaştaki artışa bağlı olarak değişebileceği öne sürülmüştür. Permeabilize düz kas modeli düz kasın kasıımasında rol oynayan proteinlerin ve hücre içi organellerin fonksiyonlarını araştırmak için değerli bir yöntemdir. Bu yöntem üriner inkontinans tedavisinde yeni ilaç moleküllerinin geliştirilmesi için genç ve yaşlı deney hayvanlarındaki kasılma yanıtlarının çalışıımasını kolaylaştırmaktadır. Günümüzde primer olarak antimuskarinik ilaçlar bu hastalığın tedavisinde kullanılsa da yan tesirleri bu ilaçların etkinliklerini kısıtlamaktadır.

Anahtar sözcükler: Yaşlı; Üriner inkontinans; Yaşam kalitesi. 


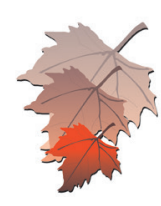

\section{INTRODUCTION}

The lower urinary tract has three main parts: the urinary bladder, urethra and the urethral sphincter complex. The urinary bladder wall consists of the mucosa, muscularis propria (also known as the detrusor muscle) and adventitia. The mucosa consists of the urothelium that comes in contact with the urine directly and at the same time acts as a blood-urine barrier against various types of pathogens, ions and molecules found in the urine. The urothelium, which has different types of receptors and ion channels, receives and then transmits information to other bladder components such as sensory nerve fibres, myofibroblasts and smooth muscle cells (1). The autonomic nervous system helps coordinate the normal bladder function by releasing mediators from the urothelium. The smooth muscles are arranged in three layers in the muscularis propria of the bladder; although in the innermost and the outermost layers, the muscles are arranged longitudinally, in the middle layer, the detrusor smooth muscle fibres are arranged in a circular manner (2).

The wall of the urinary bladder mainly consists of the detrusor smooth muscles, which play an important role in urine storage, filling and emptying. Urine is continuously produced by the kidneys, whereas voiding is not a continuous process. In a healthy young adult, the function of the urinary bladder depends on the synchronised relaxation of the detrusor smooth muscles and contraction of the urethral sphincter during urine storage; during micturition, the situation is the complete opposite. These functions are all elicited by the coordinated activity of the spinal cord, pons and excitatory, inhibitory and sensory nerves in the forebrain. The innervation of the bladder is obtained by the actions of the cholinergic, nitrergic, purinergic, monoaminergic and peptidergic mechanisms (3). Detrusor sensitivity to agonists, its spontaneous activity and the levels of the contractile proteins may vary under situations such as urethral obstruction, urinary incontinence and aging.

\section{AGING AND BLADDER FUNCTIONS}

Aging causes changes in many organs and bodily functions, including a significant decrease in the filling, storage and emptying functions of the bladder. Among the symptoms of this decrease in the various bladder functions, the more pronounced ones are reduced voiding efficiency and bladder overactivity that may lead to a concern, i.e. urinary incontinence, which affects the patient's quality of social life (4). In particular, in women, high impact exercising and childhood enuresis are found to be related with further development of urinary incontinence and so mechanisms associated with pelvic floor gain importance in prevention of this disease (5). Urinary incontinence incidences increase with age, and the side effects of the currently used drugs hinder successful treatment. In parallel with age, bladder outlet obstruction, sphincter injury, polypharmacy and urinary tract infections may also lead a pronounced urinary incontinence in the patient (6).

There are several studies, particularly on rats, examining the effects of aging on the bladder. Although it seems that the contractile proteins are not affected by aging, several studies have shown that intracellular mechanisms involving secondary messengers may alter with aging and affect the response of the bladder to agonists (7).

Voiding occurs approximately eight times a day in a healthy young adult. The urinary bladder can adjust its volume to more than $500 \mathrm{ml}$ without any increase in the intravesical pressure, allowing the storage of a large amount of urine. During the filling phase, the increase in the intravesical pressure does not exceed the filtration pressure, preventing renal failure. The relaxation of the bladder supported by the resistance of the internal and external urethral sphincter aids the filling phase. On the contrary, the voiding phase starts with the contraction of the bladder accomplished by a low outflow resistance. The autonomic and somatic nervous systems control the smooth and the skeletal muscle contractile 
activity of the urinary bladder and urethra to sustain the filling and the voiding phases (8). Therefore, to understand the pathophysiology of incontinence and to develop further treatments, one should focus on how the smooth muscle of the urinary bladder, i.e. the detrusor muscle, is affected by the aging process.

Activation of the muscarinic receptors is primarily responsible for the sustained contraction necessary for the emptying of the urinary bladder. $M_{2}$ and $M_{3}$ muscarinic receptor subtypes have been identified in rat and guinea pig bladders (and in taenia caecum), of which the $M_{3}$ receptor subtype has been shown to mediate the contraction in these three tissues. It has been reported that both $M_{2}$ and $M_{3}$ receptor subtypes are involved in normal rat bladder contractions, with the $\mathrm{M}_{3}$ subtype activating PI-PLC, PC-PLC, and PKA and the $\mathrm{M}_{2}$ subtype activating ROK and $\mathrm{PKC}$ through an additional contractile signal transduction mechanism (9). Detrusor sensitivity to agonists such as carbachol, prostaglandins and serotonin, its spontaneous activity, and contractile proteins levels can change in some conditions, such as during urinary incontinence. Therefore, it is important to understand the mechanisms underlying agonist-induced contractions in the detrusor smooth muscles to further develop therapeutic management strategies for bladder instability associated with the incontinence.

\section{DETRUSOR IMPAIRMENT PATHWAYS}

Smooth muscle contraction is primarily brought about by an increase in cytosolic calcium produced by calcium entry through voltage-sensitive calcium channels or by calcium release from the sarcoplasmic reticulum [often via a mechanism involving the $\mathrm{Ca}^{2+}$ mobilising messenger inositol triphosphate $\left.\left(\mathrm{IP}_{3}\right)\right]$. The main intracellular calcium store is the "sarcoplasmic reticulum." Calcium release from the sarcoplasmic reticulum can be mediated by both ryanodine and $\mathrm{IP}_{3}$ receptors. The two mechanisms of calcium release from the internal calcium stores, calcium-induced calcium release $(\mathrm{CICR})$ that is sensitive to ryanodine and $\mathrm{IP}_{3^{-}}$ induced calcium release (IICR), take place in smooth muscles, i.e. the detrusor muscles in the urinary bladder (10). Agonists activating G-protein-coupled receptors (GPCRs) increase force in the smooth muscles via calcium/calmodulin-dependent myosin light-chain phosphorylation. The ratio of activities of calcium/calmodulin-dependent myosin light-chain kinase (MLCK) and myosin light-chain phosphatase (MLCP) determines the level of myosin light-chain phosphorylation and hence the activation of the smooth myocytes. Inhibition of MLCP can be induced directly by Rho-kinase (ROK) or by phosphorylation of the phosphatase inhibitor CPI-17 through protein kinase C (PKC). There are, however, mechanisms, which can lead to muscle contraction without any necessary change in intracellular calcium ([Ca $\left.{ }^{2+}\right]$ i). When $\left[\mathrm{Ca}^{2+}\right] \mathrm{i}$ and MLCK activity is constant, agonists activating GPCRs may cause a leftward shift of the calcium/force response curve, (calcium sensitisation). A major pathway that can cause this operates through ROK and PKC and is thought to involve the inhibition of myosin phosphatase activity under constant calcium conditions, thereby enhancing myosin light-chain phosphorylation and causing an increase in force $(11,12)$.

In recent years, two other major intracellular $\mathrm{Ca}^{2+}$ mobilising messengers, cyclic adenosine diphosphate ribose (CADPR) and nicotinic acid adenine dinucleotide phosphate (NAADP), have been implicated in the pharmacomechanical coupling of the smooth muscles. In a previous study, we provided the first systematic analysis of the ability of $\mathrm{IP}_{3^{\prime}}$ CADPR and NAADP to cause contraction in the smooth muscles, and using the permeabilised urogenital tract smooth muscles, we showed that these $\mathrm{Ca}^{2+}$ mobilising messengers along with $\mathrm{IP}_{3}$ evoke contractions. NAADP uniquely mobilises acidic calcium stores, likely activating the two-pore channel protein 2 (TPC2), a key component of the NAADP receptor (13). The proposal that the TPC family involves $\mathrm{Ca}^{2+}$-permeable channels regulated 
by NAADP was a promising development that may be used for new drug therapy innovations in elderly people suffering from urinary incontinence.

\section{PERMEABILISED DETRUSOR}

The intracellular mechanisms of contractions, including calcium sensitisation, can be studied using chemically permeabilised smooth muscle preparations in which the plasma membrane is permeabilised using a chemical substance. In these preparations, the external and internal media contain the same ions (which can be manipulated). Chemically permeabilised smooth muscle is an experimental model for studying the intracellular organelles and signal cascades responsible for agonist-induced smooth muscle contraction and hence investigating the different levels of molecular control. For instance, $\beta$-escin is a saponin ester, which opens the pores of the plasma membrane and makes the cell membrane permeable to higher molecular weight compounds (up to $150 \mathrm{kDa}$ ), including heparin and $\mathbb{I}_{3^{\prime}}$ and retains receptor-effector coupling (14). We also used the $\beta$-escin permeabilisation method while investigating how aging affects the intracellular calcium movements due to carbachol-induced contractions in permeabilised female rat bladder smooth muscles. In this study, we observed that carbachol-induced contractions decrease with age in rat bladder detrusor as a result of a reduction in calcium-induced calcium release (CICR), rather than carbachol-induced calcium sensitization. We believe that these results obtained constitute a positive contribution to the development of new drug molecules in the treatment of urinary incontinence (15).

We have developed a functional permeabilised smooth muscle preparation to be used in rat, mouse and guinea pig bladders and by using this method, we have observed many intracellular mechanisms including Rho kinase and protein kinase $C$ pathways revealing important data on how agonist-induced contractile responses may change from one species into another or also under disease states $(13,16)$. This preparation retains sensitivity to membrane receptor agonists and can be activated by the exogenous application of intracellular messengers causing contractions. $\beta$-escin is a saponin ester that opens the pores in the plasma membrane of cells, allowing the passage of molecules having a molecular weight of up to 30000-40000 kilodalton. The ability to introduce larger molecules into the cell makes $\beta$-escin a preferable molecule for the study of the pathways mediating agonist-induced contractile responses in the smooth muscles by retaining receptor-effector coupling and at the same time enabling the access of heparin and calmodulin into the cells. Smooth muscle preparations treated with $\beta$-escin have been shown to respond to excitatory agonists through the $\mathrm{IP}_{3^{-}}$ mediated release of $\mathrm{Ca}^{2+}$ and have also shown calcium sensitisation as in our studies investigating the agonist-mediated intracellular pathways, i.e. affected under pathological conditions like urinary incontinence $(13,15,16)$.

\section{AGING AND INTRACELLULAR MECHANISMS}

Investigating the roles of intracellular calcium signalling pathways in the treatment of urinary incontinence is a new therapeutic approach. This has evolved owing to the pronounced role of ROK in the regulation of urinary bladder smooth muscle tone and contraction demonstrated in many studies. It has also been suggested that variations in agonist-induced contractions due to aging depend on impairments in the intracellular signal transduction pathways. Furthermore, it was observed that the decreased response of the bladder to $\beta$-adrenergic stimulation due to aging is related to both an inhibition in the adenylyl cyclase activity and changes in the $G$ protein content or function (17). However, the intracellular mechanisms underlying the functional changes that may occur with aging in the bladder have not been completely explained. 


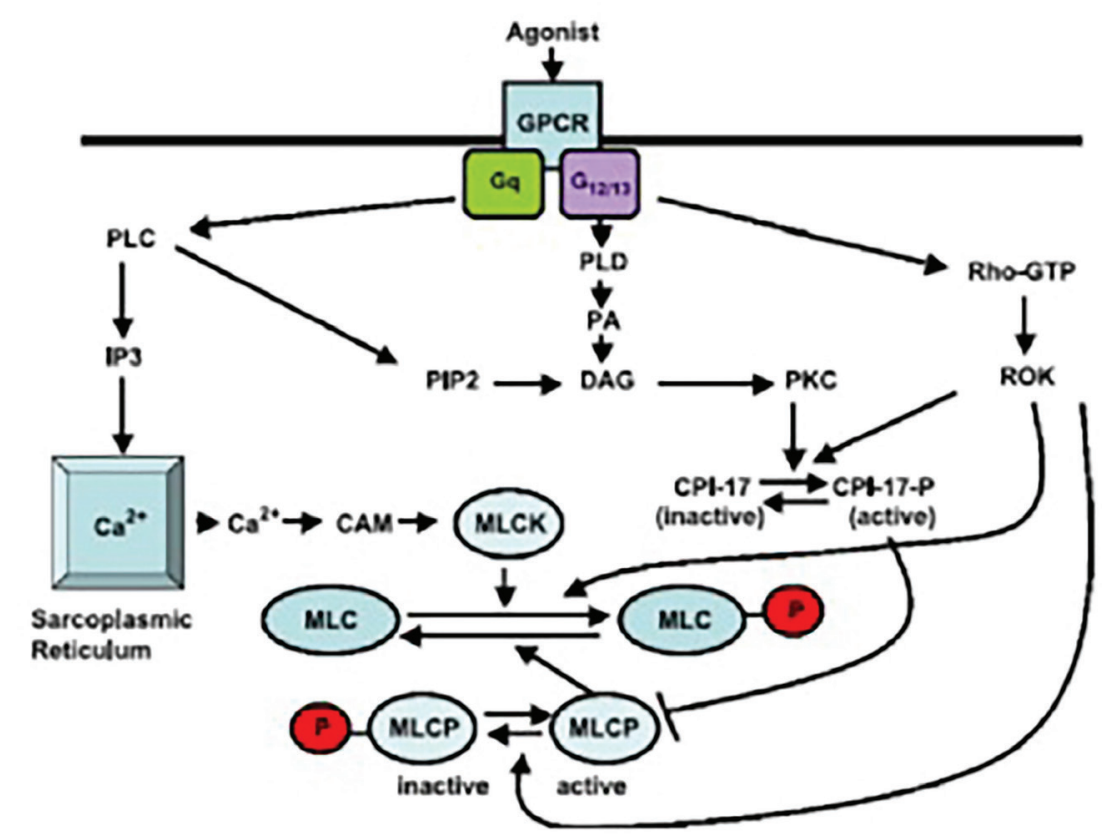

Figure 1. Mechanism of smooth muscle contraction and calcium sensitisation (12).

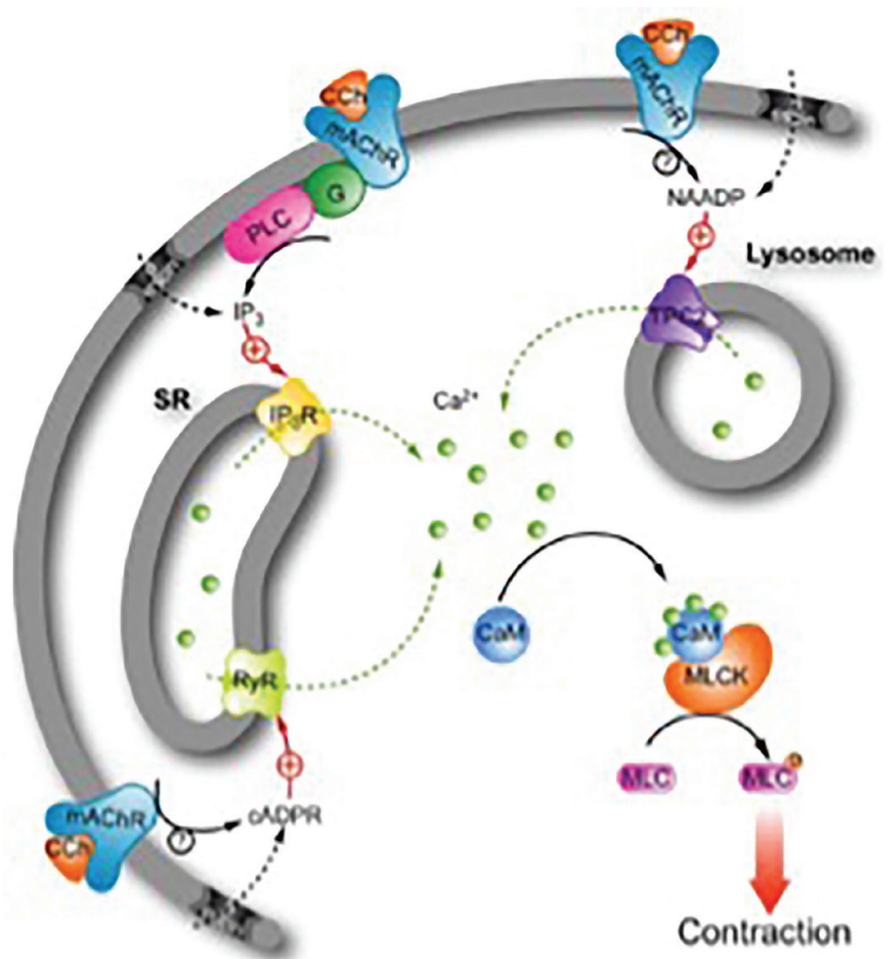

Figure 2. Receptor-mediated $\mathrm{Ca}^{2+}$ signalling pathways in the detrusor smooth muscles. Muscarinic receptor activation causes release of $\mathrm{Ca}^{2+}$ from both sarcoplasmic reticulum and lysosomal stores (13). 
Another promising area of investigation with respect to the pathophysiology and treatment of urinary incontinence is the contribution of one of the endogenous gas mediators, hydrogen sulphide. Interstitial cystitis is a syndrome characterised by chronic inflammation of the bladder in which detrusor smooth muscle contractions may vary. It is known as a syndrome of bladder hypersensitivity that is characterised by bladder sensation and fullness, i.e. urgency to urinate even with a low volume of urine. It has been known that carbacholinduced contractions in the bladder of rats increase in cyclophosphamide-induced experimental cystitis. However, the mechanism underlying this change is unclear. Because inflammation, like other abnormal changes, may cause an impairment in bladder functions leading to increased urination frequency (overactive bladder syndrome), this may easily lead to urinary incontinence. Overactive bladder syndrome, with concomitant interstitial cystitis, is a chronic disease characterised by suprapubic pain depending on bladder filling. Escherichia coli is responsible for the majority of urinary tract infections, and it may cause interstitial cystitis. Therefore, interstitial cystitis is a syndrome often caused by overactive detrusor and chronic inflammation of the bladder and may alter the contractile function of the bladder detrusor smooth muscles. Under pathological conditions, muscarinic receptor subtypes in the bladder change and particularly in cases of bladder inflammation, it was determined that contractile responses decreased due to changes in cholinergic responses (18). In a recent paper, endogenous hydrogen sulphide was shown to play a role in bladder pain through the activation of T-type calcium channels in mice with cyclophosphamide-induced cystitis (19).

\section{DRUG THERAPY IN ELDERLY WITH URINARY INCONTINENCE}

Antimuscarinic drugs are still the first line therapy in the treatment of urinary incontinence (20). Although they have a good initial response, because these drugs are typically used for many years, their efficacy decreases and rate of adverse effects increases over time. Ones treating the patients should be aware of the adverse effects of these drugs and apply a pharmacotherapy that is individually developed (21). Hence, the long-term necessity of new drug therapies is inevitable.

There are some therapies targeting the urothelium of the urinary bladder. For instance, nerve growth factor (NGF) antibodies are thought to be effective in the treatment of urinary incontinence. However, because these drugs block all NGFs involved in many physiological situations throughout the body, the incidence of adverse effects is very high. Additional treatment candidates might be the use of muscarinic receptor antagonists, purinergic receptor antagonists and prostaglandin receptor antagonists (20).

Drugs that act on the detrusor smooth muscles are more important in terms of reducing the severity of incontinence symptoms in the elderly. One of the drugs that has been used for many years is from the muscarinic receptor antagonist family, namely, acetylcholine. Acetylcholine is mainly effective in the filling phase of the bladder, and to an extent, it increases the voiding contraction. However, its secondary effect occurs at high doses and leads to adverse effects that are not acceptable to patients (20). Another group acting on the smooth muscles is $\beta 3$ adrenergic receptor agonists, which promise a decrease in urgency and a relief from urinary incontinence. A prototype drug from this group is miragebron (22). Particularly, in elderly males with both incontinence and erectile dysfunction, phosphodiesterase type 5 inhibitors such as sildenafil or tadalafil could be good therapeutic candidates, but their use in females remains unclear (23). Depending on the research mentioned above on the ROK pathways involved in incontinence, ROK inhibitors may also be effective treatment candidates. Unfortunately, currently, there is insufficient information about their potential adverse effects (24). 


\section{BOTULINUM TOXIN A}

Intravesical botulinum toxin A (BTX-A) is a potential treatment for incontinence emanating from interstitial cystitis. BTX-A is a very potent neurotoxin derived from the anaerobic bacterium Clostridium botulinum. It inhibits the release of the neurotransmitter acetylcholine at the neuromuscular junction and therefore decreases the muscle contractility at the injection site. This intravesical therapy is generally well-tolerated by the elderly population, particularly women. However, some adverse effects may occur, i.e. dysuria, haematuria, impaired detrusor contractility and a decrease in the voiding strength. Such patients on BTX-A therapy also show a high incidence of urinary tract infections (particularly of those caused by viruses) (25). However, BTX-A treatment does not cause adverse effects such as dry mouth, constipation, dyspepsia and dizziness that commonly occur with antimuscarinic therapy, thus increasing patient compliance.

Moreover, there might be drug combinations to help the elderly who suffer with the symptoms of incontinence. Alpha 1-adrenergic antagonists and 5-alpha reductase inhibitors are two such examples (20).

\section{REFERENCES}

1. Andersson KE, Arner A. Urinary bladder contraction and relaxation: physiology and pathophysiology. Physiol Rev 2004;84(3):935-86. (PMID:15269341).

2. Michel MC, Igawa $Y$. Therapeutic targets for overactive bladder other than smooth muscle. Expert Opin Ther Targets 2015;19(5):687-705. (PMID:25704500).

3. de Groat WC, Yoshimura N. Pharmacology of the lower urinary tract. Annu Rev Pharmacol Toxicol 2001;41:691-721. (PMID:11264473).

4. Smith PP. Aging and the Underactive Detrusor: A Failure of Activity or Activation? Neurourol and Urodyn 2010;29:408-12. (PMID:19760756).

5. Almousa $S$, van Loon $A B$. The prevalence of urinary incontinence in nulliparous adolescent and middleaged women and the associated risk factors: A systematic review. Maturitas 2018;107:78-83. (PMID:29169586).

\section{CONCLUSION}

It is well known that the prevalence of bladder dysfunctions, i.e. impaired urine storage and voiding performance, increases with age. In the human urinary bladder, due to the aging process, it is difficult to determine the exact reasons underlying the impairment of the detrusor. There are useful data obtained from studies conducted on age-related changes in animal models. However, both morphological changes and intracellular signal transduction pathway impairments may lead to incontinence in the elderly population. Impaired contractility may be related to different pathophysiological changes due to aging. Therefore, among the drug therapies that are available, those aiding in curing symptoms might lead to many adverse effects in elderly people. Due to improved data on intracellular pathways involved in incontinence, there are now good candidates for new therapeutic agents. The use of hydrogen sulphide and similar agents might be important in developing new drug therapies for incontinence.

6. Hester AG, Kretschmer A, Badlani G. Male Incontinence: The Etiology or Basis of Treatment. Eur Urol Focus Oct;3(4-5):377-84. (PMID:29249687).

7. Derweesh IH, Wheeler MA, Weiss RM. Alterations in G-proteins and beta-adrenergic responsive adenylyl cyclase in rat urinary bladder during aging. J Pharmacol Exp Ther 2000;294(3):969-74. (PMID:10945848).

8. Fry $\mathrm{CH}$, Meng $\mathrm{E}$, Young JS. The physiological function of lower urinary tract smooth muscle. Auton Neurosci 2010;154(1-2):3-13. (PMID:19939745).

9. Braverman AS, Tibb $A$, Ruggieri MR. $M_{2}$ and $M_{3}$ muscarinic receptor activation of urinary bladder contractile signal transduction. I. Normal rat bladder. J Pharmacol Exp Ther 2006;316(2):869-74. (PMID:16243961).

10. Wibo M, Godfraind T. Comparative localization of inositol 1,4,5-trisphosphate and ryanodine 
receptors in intestinal smooth muscle: an analytical subfractionation study. Biochem J 1994;297(Pt 2):415-23. (PMID:8297349).

11. Somlyo AP, Somlyo AV. $\mathrm{Ca}^{2+}$ sensitivity of smooth muscle and nonmuscle myosin II: modulated by G proteins, kinases, and myosin phosphatase. Physiol Rev 2003;83(4):1325-58. (PMID:14506307).

12. Watterson KR, Ratz PH, Spiegel S. The role of sphingosine-1-phosphate in smooth muscle contraction. Cell Signal. 2005;17(3):289-98. (PMID:15567060).

13. Tugba Durlu-Kandilci N, Ruas M, Chuang KT, Brading A, Parrington J, Galione A. TPC2 proteins mediate nicotinic acid adenine dinucleotide phosphate (NAADP)- and agonist-evoked contractions of smooth muscle. J Biol Chem 2010;285(32):24925-32. (PMID:20547763).

14. Kitazawa T, Kobayashi S, Horiuti K, Somlyo Av, Somlyo AP. Receptor-coupled, permeabilized smooth muscle. Role of the phosphatidylinositol cascade, G-proteins, and modulation of the contractile response to $\mathrm{Ca}^{2+}$. J Biol Chem 1989;264(10):5339-42. (PMID:2494163).

15. Durlu-Kandilci NT, Denizalti M, Sahin-Erdemli I. Aging changes agonist induced contractile responses in permeabilized rat bladder. Age 2015;37(4):9807. (PMID:26153091).

16. Durlu-Kandilci NT, Brading AF. Involvement of Rho kinase and protein kinase $\mathrm{C}$ in carbachol-induced calcium sensitization in beta-escin skinned rat and guinea-pig bladders. Br J Pharmacol 2006;148(3):37684. (PMID:16565731).

17. Kirschstein T, Protzel C, Porath K, Sellman T, Köhling R, Hakenberg OW. Age-dependent contribution of Rho kinase in carbachol-induced contraction of human detrusor smooth muscle in vitro. Acta Pharmacol Sin 2014;35(1):74-81. (PMID:24122009).
18. Palea S, Artibani W, Ostardo E, Trist DG, Pietra C. Evidence for purinergic neurotransmission in human urinary bladder affected by interstitial cystitis. J Urol 1993;150(6):2007-12. (PMID:8230554).

19. Matsunami M, Miki T, Nishiura $K$, et al. Involvement of the endogenous hydrogen sulfide/Ca(v) 3.2 T-type $\mathrm{Ca}^{2+}$ channel pathway in cystitis-related bladder pain in mice. $\mathrm{Br} J$ Pharmacol 2012;167(4):917-28. (PMID:22646666).

20. Andersson KE. Drugs and future candidates. Can Urol Assoc J 2011;5(5Suppl2):S131-3. (PMID:21989523).

21. Geoffrion R. No. 283-Treatments for Overactive Bladder: Focus on Pharmacotherapy. J Obstet Gynaecol Can 2018;40(1):e22-e32. (PMID:29274717).

22. Chapple CR, Dvorak V, Radziszewski P, et al. A phase Il dose-ranging study of mirabegron in patients with overactive bladder. Int Urogynecol J 2013;24(9):144758. (PMID:23471546).

23. McVary KT, Roehrborn CG, Kaminetsky JC, et al. Tadalafil relieves lower urinary tract symptoms secondary to benign prostatic hyperplasia. J Urol 2007;177:1401-7. (PMID:17382741).

24. Morelli A, Vignozzi L, Filippi S, et al. BXL-628, a vitamin $D$ receptor agonist effective in benign prostatic hyperplasia treatment, prevents RhoA activation and inhibits RhoA/Rho kinase signaling in rat and human bladder. Prostate 2007;67:234-47. (PMID:17163492).

25. Tirumuru S, Al-Kurdi D, Latthe P. Intravesical botulinum toxin $A$ injections in the treatment of painful bladder syndrome/interstitial cystitis: a systematic review. Int Urogynecol J 2010;21:12851300. (PMID:20449567). 